\title{
Inhibitory Effects of Chalcone on the Replication of Poliovirus in Vitro
}

\author{
Abdullatif M.Ahmed ** \\ Noor H.Kareem* \\ Gassaq T.Sadiq* \\ Mohamed O.Abdullatif*
}

Received 1, April, 2009
Accepted 19, April , 2012

\begin{abstract}
:
The compound chalcon originally is extracted form some plant and herbs, the studies of the antiviral activity of this compound were done in two cell line cultures the $\mathrm{L} 2 \mathrm{OB}$ and $\mathrm{RD}$, the compound relatively non toxic to both cell lines of the concentration of $32 \mu \mathrm{g} / \mathrm{ml}$ or less ,the compound have significantly anti poliovirus activity in both L2OB cell line and RD cell line, we find that the concentration of 0.03 $\mu \mathrm{g} / \mathrm{ml}$ or more inhibit the 100TCDID50 of the poliovirus .The therapeutic index(TI)used in this study to evaluate the drug activity, ( TI is the ratio of dose of drug which is just toxic to the cells to the does which is just inhibit the viral multiplication, if this index more than one the margin of safety of drug is according great ) .In this study the TI of chalcone against poliovirus is 266,therefore this compound if used in man have little or no side effect.
\end{abstract}

Keyword: poliovirus; antiviral; chalcone; flavons

\section{Introduction :}

Poliovirus infections of the nervous system have largely eliminated by immunization, the disease is caused by one of the poliovirus serotypes $(1,2$ and 3) which are belong to the family picornaviridae subdivision of enteroviruses group.This virus causes meningitis and infects the gray matter of the spinal cord,brain stem and cortex, although poliovirus that causes a nonspecific gasteroenteritis, the nervous system invaded secondary especially the anterior horn cells in the lumber segments. The death occurs due to respiratory paralysi. Muscle weakness due to poliovirus infection showing no signs of recovery; the muscle probably will not regain useful function. Since the aim of this study was to find further antipolioviral treatment. Nevertheless the need for antiviral compound that have the ability to across the blood-brain barrier, nontoxic, and effectiveness. We have presented in this study, one of the flavonoid compound (the Chalcone), such compound can be isolated from many herbs and plants such as beans, tomatoes, grape fruit and they have the ability to across the blood-Brain barrior[1,2,3,4].

The antiviral chalcone have an antiviral activity against rubella in tissue culture and against rhinovirus in vitro and in human [5, 6, 7]; it is nontoxic to cell, and has been shown in vitro using two cell lines L2OB and $\mathrm{RD}$ cells against poliovirus type 1 and 3 ; they are clearly and significantly showed an antiviral activity against poliovirus and by the using of therapeutic index $[8,9]$.

\footnotetext{
**Hawler Medical University, College of Medicine

*Al-Nahrain University, Biotechnology Research Center
} 


\section{Material sand Methods : \\ Cells}

RD cells: The cells were propagated and maintained in Eagles Minimum Essential medium (MEM) gibco supplemented with $10 \%$ fetal calf serum (FCS) as growth medium, or $2 \%$ FCS as maintenance medium.

L20B cells: The cells were propagated and maintained in Eagles Minimum Essential medium (MEM) gibco supplemented with $10 \%$ fetal calf serum (FCS) as growth medium, or $2 \%$ FCS as maintenance medium.

\section{Viruse}

Attenuated poliovirus type 1 (PV 1) and poliovirus type 3 (PV3) were obtained from CPHL. Viruses were grown in RD cells Or L20B cells monolayer, cultured in MEM supplemented with $2 \%$ FCS. Cultures were harvested at maximum cytopathic effect (CPE), to getrid from the cell debris and to have virus only ; freezing and thawing of the culture three times then clarified by centrifugation and the supernatant which containing the virus stored at $-70^{\circ} \mathrm{C}$.

\section{Virus titration}

Virus infectivity was assayed by titration in microtitre plates with confluent monolayer of L20B cells, using serial two -fold dilution and 3 or 4 wells per dilution, $50 \%$ end points were calculated according to reed and much (1942). The virus infectivity was measured by Cytopathic Effect (CPE).

\section{Chemicals}

The compound chalcone (4-ethoxy2hydroxy-4, 6-dimethoxy chalcone) was prepared and supplied by NipponRoche research center, Kamakura, Japan.

\section{Results:}

Toxicity of chalcone was estimated by incorporating varying amount of the drug $(1-12 \& u g / m l)$ in tissue culture maintenance media of RD cells and L20B cells and adaily microscopic examination of the cells for toxic effect such as floating cells, cells, cell granulation or any alteration of cell shape. Observations were recorded daily until the end of the incubation period (4 to 5 days), concentration of $32 \mu \mathrm{g} / \mathrm{ml}$ or greater were rapidly toxic while a concentration of $16 \mu \mathrm{g} / \mathrm{ml}$ were toxic on day 2.The concentration of 8 $\mu \mathrm{g} / \mathrm{ml}$ or less showed no toxic effect to the cell culture used in this study(table $1)$.

The determination of the minimal inhibitory concentration (MIC) of chalcone was measured by serial 2 -fold dilution of the just below the toxic concentration of the chalcone to the cell culture (4 $\mu \mathrm{g} / \mathrm{ml})$. These concentration of charcone were added at the same time to the addition of 100TCD50 of PV1 to wells of 96 wells microtiter plate containing confluent monolayer of RD cells or L20B cells (4 wells for each concentration); then the cell observed daily for 5 days for the production of $\mathrm{CPE}$, concentration of $0.06 \mu \mathrm{g} / \mathrm{ml}$ or more completely inhibit CPE of PV1 and PV3 in L20B, while a concentration of $0.125 \mu \mathrm{g} / \mathrm{ml}$ or more completely inhibit PV1 and PV3in RD cells and a concentration of $0.06 \mu \mathrm{g} / \mathrm{ml}$ inhibit $75 \%$ of CPE in RD cells (table1), while a concentration of $0.015 \mu \mathrm{g} / \mathrm{ml}$ and less have no effect on the virus; therefore the $\mathrm{T} 1$ of charcone against both PV1 and PV3 in RD cells and L20B cells are 266. 
Table(1):Potency and cytotoxicity of drug against poliovirus 1 and 3

\begin{tabular}{|c|c|c|c|c|c|c|}
\hline \multirow{2}{*}{$\begin{array}{l}\text { Drug } \\
\text { conc. } \\
\mu \mathrm{g} / \mathrm{ml}\end{array}$} & \multicolumn{3}{|c|}{ Production of CPE by RD } & \multicolumn{3}{|c|}{ Production of CPE by L20B } \\
\hline & No virus & PV1 & PV3 & No virus & PV1 & PV3 \\
\hline 32 & $\mathrm{~T}$ & $\mathrm{~T}$ & $\mathrm{~T}$ & $\mathrm{~T}$ & $\mathrm{~T}$ & $\mathrm{~T}$ \\
\hline 16 & $\mathrm{~T}$ & $\mathrm{~T}$ & $\mathrm{~T}$ & $\mathrm{~T}$ & $\mathrm{~T}$ & $\mathrm{~T}$ \\
\hline 8 & NT & - & - & NT & - & - \\
\hline 2 & NT & - & - & NT & - & - \\
\hline 0.5 & NT & - & - & NT & - & - \\
\hline 0.125 & NT & - & - & NT & - & - \\
\hline 0.06 & NT & + & ++ & NT & - & - \\
\hline 0.03 & NT & ++++ & ++++ & NT & ++++ & ++++ \\
\hline 0.015 & NT & ++++ & ++++ & NT & ++++ & ++++ \\
\hline 0 & NT & ++++ & ++++ & NT & ++++ & ++++ \\
\hline
\end{tabular}

NT: No Toxic; T: Toxic; -: No CPE; +: 25\% CPE;

++: 50\% CPE; ++++: $100 \% \mathrm{CPE}$

\section{Discussion :}

In spite of relatively extensive efforts to develop antiviral drugs limited numbers of compounds which can be used in man or animal have become available. The reason for this is the difficulty in finding substances which selectively influences the replication of virus without having toxic effect on cells. The evaluation of antiviral compounds can be qualified by using therapeutic index.

The present studies on the toxicity of the chalcone confirm that this compound relatively non-toxic with an inhibitory effect against PV1 and PV3in RD and L20B cell system assessed. The susceptibility of PV1 and PV3 to the compound could be demonstrated by inhibition of $\mathrm{CPE}$ produced by 100TCID50 in tissue culture of RD cells, and L20B cells. However we find that the sensitivity of virus to the drug varied between different experiment, the variation may be due to differences between batches of cell or may also partly be due to change in the drug concentration because the drug concentration was not prepared freshly each time but prepared from the stock solution. Furthermore the sensitivity of PV1 and PV3 to the drug was less in RD cells than L20B cells. The virus titration in RD cells and L20B cells were same. This suggested that the lack of inhibition by the drug may have been partly due to behavior of the drug in the different cells, rather than to insusceptibility of the virus to the drug.

Since the inhibition of CPE is relatively simple test it has some value for preliminary experiments to evaluate antiviral drugs. It seemed probable that a more sensitive test based on plaque titration might have given more accurate and reproducible result, indeed we find that this method give nearly the same results with our previous experiments [10].

It is important to bear in mind that the condition of human experimental studied differ from that done in tissue culture. Bucknal indicated that $70 \%$ of compound active against viruses in tissue culture failed to inhibit viral multiplication in organ culture or in animals [11, 12]. 


\section{Referenceses :}

1. Ishitsuka , H.,Ohiwa, T. and Sahara, Y 1982. Antipicornavirus flavones . Antimic. Age. and chemo. 22 (4):611616.

2. Paolacci, A.R, Ovidio, RD and Marbottini , R 2001. Includes a differentiation accumulation of phenylalanine ammonium logos chalcone in sensitive and resistance bean cultivars. J. plant phys. (2):2837.

3. Verboten, M.E., Bovey,A., Collins, G. and Colliver, S. 2002 . Increasing antioxidant levels in tomatoes through modification of flavonoids biosynthetic pathway. J . exp botany 53 (377) :2099-3006.

4. Mitsunaga,Y.,Takanaga, H., Natio, M. and Sawada, Y. 2000. Effect of bioflavonoid on incrusting transport across blood-brain barrier. Eur. J. pharmacol. 2000 may 3;395(3): 193201.

5. Ahmad, A.L.M and Tyrell, D.A.J. 1986. Synergism between antirhinovirus antiviral. Antivir. Res. (6):241-250.

6. Phillpott, R.J., Higgins, P.G. and Tyrell, D.A.J. 1984. Evaluation of rhinovirus chalcone given orally to volunteers. J. antim. Chemoth. (14):403-409.

7. Ahmad, A.L.M, Abdurrahman, A. and Abdullatif, M.O. 2008. The Antiviral activity of the compound chalcone against rubella virus in vitro. Um-Salama J. Sci 5(3):391-395

8. Ninomiya, Y., Acytoma, M., Umeda, A. and Ishetesoka, H. 1985. Comparative activity of the compound chalcone, dichloroflavan and enviroxime. Antimic. Age. Chemo. 27(4):595-599.

9. Graham, J. 1967. Pharmacology for medical students. Oxford Univ. Press.

10. Al-Khayat'Z.A. and Ahmad A.L.M. 2012 Antiviral activity of enviroxime against poliovirus and rubellavirus in tissue culture. Ibnosina J Med. and Biomed. Vol 4:12-16.

11. Ahmad A.L.M. 2012 Synargesim between the compound dichloroflavine and chalcone aganst poliovirus in vitro. J. biotech. Res. Cent. 6 (1) 26-31

12. Bucknall, R.A. 1973. The continuing search for antiviral drug. Adv. Pharmacol. Chemo. (11):295301. 


\section{التأثير المثبط لمركب الجالكون على تكاثر فايروس شلل الاطفال في الزرع النسيجي نائر ناير}

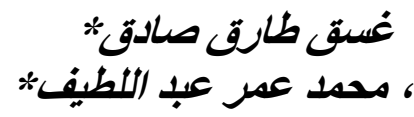

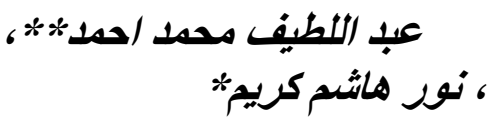

|*لية الطب/جامعة هولير الطبيه

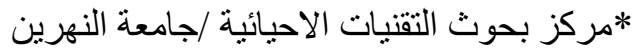

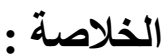

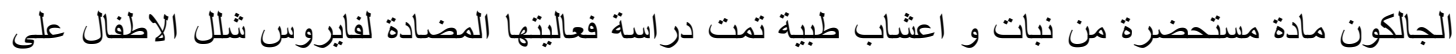

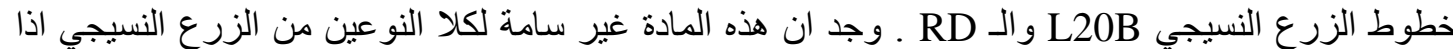

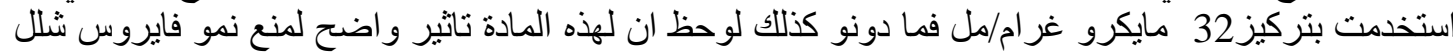

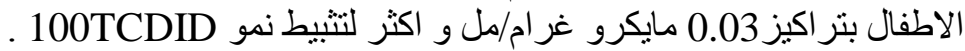
و باستخدامنا الدليل العلاجي (الذيكي هو نسبة اقل تركيز سمي للمادة على اقل تركيز لهذه المادة المنبطة لنمو . 100TCDID ومن هذه النتائج وجد الدليل العلاجي لهذه المادة ضد فايروس شلل الاطفال هو 266 و الذي يعني ان اعراضه

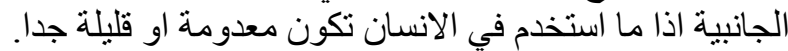
الكلمات المفتاحية:- جالكون ، مضاد فايروسي، فلافون، فايروس شلل الاطفال. 